\title{
Evaluation of Collaborative Learning Settings in 3D Virtual Worlds
}

\author{
doi:10.3991/ijet.v4s3.1112 \\ Vanessa Chang $^{1}$, Christian Gütl ${ }^{1,2}$, Simone Kopeinik ${ }^{1,2}$, Robert Williams ${ }^{1}$ \\ ${ }^{1}$ Curtin University, Perth, Australia \\ ${ }^{2}$ TU Graz, Graz, Austria
}

\begin{abstract}
Virtual 3D worlds are gaining popularity among the general population and the virtual world environment is widely used particularly by the younger generations as a knowledge and social tool. In recent years, universities have conducted experiments with the use of virtual 3D worlds for teaching and learning. Virtual 3D worlds are no longer just for the stereotypical geek. By 2011 it is estimated that about $80 \%$ of active Internet users will have an "avatar" and/or a "second life" in some form of virtual world environment. This paper attempts to contextualize the evolution and generations of learners for learning in the $21^{\text {st }}$ century. This paper presents a virtual learning environment created using Second Life equipped with four types of virtual space - collaborative area, common area, teacher-student meeting area, and social recreation area. An experiment is conducted involving university students who are enrolled in a unit with the aim of evaluating the use of Second Life for collaborative learning. A pre-survey evaluation was gathered followed by a post-survey evaluation. The positive results of these evaluations as well as lessons learned during the implementation phase are discussed in this paper.
\end{abstract}

Index Terms-Virtual 3D world; learning environment; collaborative learning; U-learning; e-learning

\section{INTRODUCTION}

The rates of technological advancement and society's expectations of higher education have changed significantly over the last century $[4 ; 17]$. Teaching at universities has gradually evolved into a learner-centered approach focusing on student learning in the modern-day learning environment rather than on traditional classroom delivery. The method of teaching ten years ago is not the method to achieve learning with this generation of learners [21]. Today's learners rely heavily on technology as an integral part of their daily lives. These new generations of learners are surrounded by wired and wireless technologies everywhere, at home, at school, and in their pockets.

The latest generation of learners, the Generation Y, also known as the Millennial or the Net Generation [24, 25], is the largest generation currently attending university. This group of students, born after 1982 is "independent, confident, ambitious, team-oriented, adaptable, expecting, empowered, determined and driven achievers who depend on technology as their support system" $[23,26]$. This generation also has characteristics that "lack of professional boundaries influenced by socialization, a need to have immediate feedback, a sense of entitlement, lack of critical thinking skills, unrealistic expectations ... this generation of learners also wants to spend less time on tasks and reach success with little effort" [21].
The learning attitudes and learning styles of Generation $\mathrm{Y}$ are vastly different when compared to the older generations [23]. This generation believes that learning must be captivating for them and they share and learn with their peers. The teachers in this respect have subsumed the role of a facilitator rather than an authority figure as it were with the Silent Generation and Baby Boomers. To be able to teach and embed technology in the curricula, it is expected that teachers must be technologically savvy, to be able to infuse games and activities into the curricula $[19,20,32]$. As seen from the above, the learning preferences, styles and educational tendencies of the current Generation Y are distinctive from those of their predecessors. And for this reason, contemporary and sustainable learning environments must be created to cater this generation of learners. In particular technology has influenced learning media and ways on how to educate and learn [16, $23,26]$.

\section{A. Generations of Learners}

To create a dynamic and flexible learning environment for today's learners, educators must understand and be aware of Generation Y learning styles and life styles [22]. Both learning styles and life styles affect the students' ways of learning. Billings [22] indicated that the current Generation $\mathrm{Y}$ is particularly receptive to learning styles that allows them to learn from experimentation. They prefer visual learning and like to work in groups, enjoy the combination of education and entertainment (or edutainment), multi-task but have a short attention span. Generation Y prefers to search information on the Internet and prefers interactive materials. Traditional resources such as hard copy books may not be effective and sufficient for this generation of learners.

In terms of learning from experimentation, the Generation Y likes to discover new things and prefer to learn by doing [26]. They like up-to-date technology. They enjoy learning through self-discovery and taking the initiative to learn new tools. The Generation $\mathrm{Y}$ is comfortable in the media and information-rich environment, surrounded by different kinds of digital devices. They are usually exposed to interactive computer games. The Generation Y enjoys the culture of the interaction and on-line environment where they meet and interact with people. Connections and community can be fostered through the use of social-networking tools. The Y generation prefers and enjoys learning and working in a supportive environment with their peers. They often use collaborative tools such as Google Apps [22]. The Y generation also builds up their learning by working with their peers. This learning characteristic fits Vygotsky's 
[29] social development theory, where the learners gain confidence and support when cooperating with peers, and they scaffold knowledge together.

This generation of learners is able to multi-task and can split their attention between different activities [30]. A Generation Y student can listen to music, surf the Internet, and talk to friends on the phone while doing homework. In this regard learning can be made interesting by embedding lessons in some form of entertainment [31]. Integrating games into education is seen to being up-to-date and an interactive way to increase students' interests. Additionally, students are more engaged and motivated when learning is interactive and involves fun activities.

\section{B. Ubiqutous Learning (U-Learning)}

Ubiquitous learning or U-Learning is a term to denote learning that occurs anytime and anywhere. U-Learning also has the connotation of 'just-in-time' learning and today's learners, particularly the current generation who grew up with instant messaging and instant feedback expect learning to be available practically at their convenience, both synchronously and asynchronously. Therefore, E-learning and U-learning are right to fit the new generation of learners' lifestyles, because they are able to pace themselves in learning without perceiving the constraints of place and time.

Today's educators must be aware of the learners' learning and lifestyle characteristics and be able to identify a strategy to implement learning [32]. A paradigm shift is occurring, and higher education cannot ignore the needs of these students. In recent time, teachers are taking on various roles in and out of the classroom to achieve student learning and successful teaching. Consequently, educational approaches must adapt accordingly $[12,20]$. Increasingly, our society and the globalization activities along with new capabilities of ICT demand new approaches for educational and life-long learning $[12,18]$.

\section{MODERN AND DYNAMIC LEARNING ENVIRONMENTS}

To illustrate a complex situation for modern learning environment, a selection of challenging aspects are outlined here, and a more detailed discussion can be found in $[5,6,7,12,15,19,20]$. Instead of structured scheduled learning sessions over a specific time period, a more natural U-learning concept of 'continual anywhere anytime learning approach' is required. By focusing on today's student attitudes and life styles, the traditional image of students, especially in higher education, has changed significantly. The design of learning programs must also cater for learners of this generation. Not only will the Generation Y learners find the new programs flexible and useful, but the programs must also attract other generations. In today's competitive and virtual world supported by technological enabled environment, coupled with the opportunities to enrol into programs with flexible delivery modes, many part-time students are also finding these programs attractive and useful for their career. Moreover, there are also growing interests from different student groups to enrol into these programs remotely. There are also students who prefer to enrol in cross institutional units or courses. As a result of this flexibility, there are organizational aspects and structures that educational in- stitutions must follow in order to cater for the different students' learning strategies and styles.

Centralized physical buildings, traditional face-to-face lectures and consultation hours are not sufficient to meet students' requirements of today's learning environment. The traditional set-up may also be restrictive to students who are unable to physically attend lectures, workshops, or meetings for health, employment or other reasons. There are also concerns of environmental protection and economic developments that may affect and prevent faceto-face meetings. For example, the 2003 pandemic SARS outbreak and the recent H1N1 Swine Flu can affect mobility of the main stakeholders in the learning process. In this regard, different learning environments to capture the challenges of the modern day student learning strategies and styles must be strategically positioned in educational institutions.

With today's advanced technological inventions, technology-supported asynchronous and synchronous communications exist to support geographically dispersed learning, working, or social environments. This may be as simple as text-based chat or as complex as virtual meeting systems $[11,16]$. The area on virtual worlds have been an active research topic, however, the technology was unavailable and was not ready for complex application scenarios until recently. New and powerful platforms and tools, such as Second Life, Active Worlds, Multiverse, Open Croquet, OpenSim and Sun's 3D Wonderland, have emerged to complement knowledge transfer and learning settings. Unlike other ICT-based solutions for distance learning, virtual 3D worlds may benefit from features such as the use of multiple communication channels, the 3D environment (eg. the awareness of other avatars [28]) and learning activities, and the decreased in barriers between students and tutors [13].

The great potential of virtual 3D worlds for knowledge transfer and education has motivated us to start research on collaborative learning and training activities for the new generations of learners. One specific focus lies in modern learning settings to support geographically dispersed environments. In this paper we will discuss the design, implementation and evaluation of a virtual 3D environment based on Second Life (SL). This environment is developed to complement traditional learning environment and support students studying a unit at the School of Information Systems at Curtin University in Australia. A situation analysis in Australia focusing on specific needs for learning settings for geographically dispersed environments and a high level requirement for a 3D learning environment are discussed in Section III. Section IV gives a snapshot of the 3D learning environment. Section $\mathrm{V}$ presents the questionnaires for the experimentation study and Sections VI and VII provide the findings from the use and development of the SL learning environment experimentation, followed by a conclusion in Section VIII.

\section{SituATION ANALYSIS AND OVERVIEW OF PLATFORM REQUIREMENTS}

The Australian Government undertook a review of the situation of the Australian's higher education in 2008 and published a report known as 'The Bradley Review of Higher Education' [3]. The review reported that "it is essential that Australia's higher education institutions pro- 
vide students with stimulating courses and teaching, a good-quality learning environment, access to support services and the opportunity to engage informally with staff and fellow students as part of a learning community, whether it is on-campus or off-campus using the latest available communication technologies" [3]. Also pointed out in the report was that 'the rhetoric term of lifelong learning must be turned into a reality' [3]. The report also indicated that access and participation rates to higher education must increase by 2010 as the current trend indicates that the supply of people with undergraduate qualifications will not keep up with industry demand for skilled workers. There are opportunities to increase the rates of participation and access from groups such as the indigenous people, those from regional and remote areas and those in the workforce. However, educators are faced with difficult challenges to improve access and equity for those from lower socio-economic backgrounds, and those from regional and remote Australia as well as indigenous Australians [3].

In 2007 , about $12 \%$ of all students (domestic and international) enrolled in higher education in Australian public universities were located in regional and remote areas [8]. To tackle the issue with access and participation, Australia needs a long term sustainable system of higher education which is flexible and innovative. An effective and sustainable approach will require collaboration and considerable effort from industry and academia to ensure a viable learning environment. A well-coordinated, systematic approach to addressing these complex issues and increasing the numbers gaining access to higher education is vital [3].

The review also invited submissions from the student body. One submission highlighted accessibility to staff as an important factor in students' learning experience. Access to staff was also a matter of particular concern for distance and indigenous students. The role of information and communication technologies (ICT) was seen as a necessary and useful tool for off-campus students to access staff and learning management system.

In an effort to bring education to those students in regional and remote areas or abroad and those in the workforce or part-time students, many institutions provide innovative ICT or learning management system for distance learning. In today's modern technological era and learning environments, using virtual 3D worlds may decrease the barriers between students and staff. Other benefits include the interaction in the $3 \mathrm{D}$ environment itself and access to the learning activities [13]. In order to create an effective learning environment encompassing virtual 3D worlds, developers must consider a high level requirement of a 3D learning environment system for collaborative learning. The requirement factors to consider are organizational, pedagogical and technological aspects. Consideration for organizational aspects include strategies to (1) complement existing learning environment with the possibility of providing alternative activities for remote learning, (2) easy to access and use learning system by students and teachers, (3) hosting of applications on the institution's servers with firewall restrictions. The pedagogical aspects include the enabling of (1) collaborative learning in small groups, (3) tutoring and teacher consultation, (3) support learning task with appropriate toolset and (4) scaffold inter-group and intra-group discussion. Lastly, the technological aspects to consider include (1) access from within and outside of campus, (2) easy to install and operate sys- tem, and (3) minimum hardware requirements for the both students and teachers.

\section{A GLIMPSE OF THE 3D LEARNING ENVIRONMENT}

Following a review of the available $3 \mathrm{D}$ environments and in accordance with the high level requirements as outlined in Section III, a Second Life (SL) learning environment was built. Second Life is a "free online virtual world imagined and created by its residents" with broad usages for social interaction, learning and business [26]. SL provides easy ways for creating objects and a huge community offers pre-existing designs, objects and tools [14].

As with social networking and interaction, there are multiple possibilities of simulating and creating new worlds for students to interact in to achieve a learning outcome. In this study, a virtual environment was created in Second Life where students are able to meet and work collaboratively in a social setting. During the design of the SL learning environment, we have followed these goals, (1) to make the environment a pleasant place to spend time in, (2) to enable and facilitate communication among users, and (3) to provide useful tools for collaborative work. The learning environment was intended to provide a productive, but also an enjoyable learning space for members to work in.

The environment was built on an island owned by Graz University of Technology and follows a room metaphor. Figure 1 shows the learning environment with building for group learning and collaboration, an office for virtual consultation hours, and an outside recreation area for social interaction. All buildings are equipped equally; each of which is meant to be used by one group of students, seen as their private group working space.

\section{A. Private Group Learning Areas}

For privacy, the group learning areas were designed as closed bungalows. The entrance doors to each area were implemented with access restriction. Only students have access to their assigned learning room and they can grant access to other students and teachers. Each collaboration room is equipped with tools to facilitate communication, discussion and collaborative learning activities. Access rights for the tools have also been implemented to secure communication and content of the learning groups. A brief overview of the tools is given as follows.

The Appointment Setter tool Figure 2) allows students and lecturers to send messages to each other. For example,

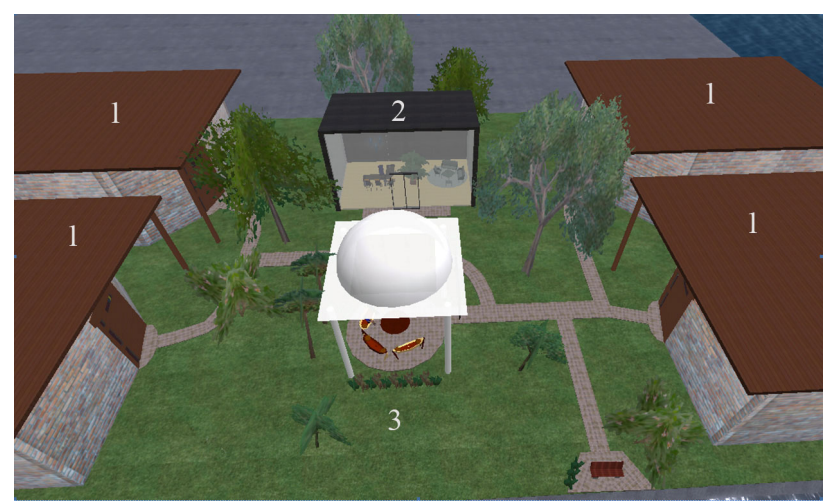

Figure 1. Overview of the Learning Environment - (1) private group learning room, (2) teacher's office, and (3) recreation area 
the agenda and the schedule of upcoming meetings can be set up using this tool without leaving the environment. The Slide Presenter Board (Figure 3) offers a platform to share presentation slides or pictures. This board can also be used to create presentations collaboratively and may also be used to initiate discussion or reflect on learning material. Each student of the learning group can add images from his/her inventory to the presentation but also individual slides can be deleted by members of the group.

The Brainstorming Board (Figure 4) is a freely available education tool, offered in SL [9]. The purpose of this tool is used to develop and express ideas collaboratively. Each time when a new brainstorming session starts, the application deletes existing content automatically and announces a particular text chat channel on which the new brainstorming would take place. Using this channel, all group members can put their suggestions on the board via text chat.

This Whiteboard tool (Figure 5) is part of an education package available in SL [1] and it can used for uploading images, drawing mind maps, presenting slides, and taking snapshots to save changes. The purpose of this tool is to scaffold the communication and collaboration process.

The Media Board (Figure 6) displays web pages and has a button which opens a browser showing the current web site. Given that SL does not provide document sharing for collaborative writing, this wall has been adjusted to access the Google Docs service. The documents can be viewed in the SL world and can be easily edited out of SL world with a Web browser. This workaround turned out to be a suitable alternative for the lack of document sharing and document authoring support within SL.

\section{B. Teacher-Student Meeting Area}

The Teacher's Office (Figure 7) provides students in the SL learning environment a place to consult with the lecturers. Two zones were designed for this, a formal and a casual setting for meetings.

\section{Social Area}

The Social Area (Figure 8) is intended to provide a recreational area for the students to relax, chat, meet, or discuss ideas with other groups. With this, the students get the feeling of being part of the world where they could get more involved and be aware of their presence in SL or the virtual environment. In order to initiate discussion a news reader panel is placed in the middle of the area which provide highlight of news of subjects related to the course or any other announcements.

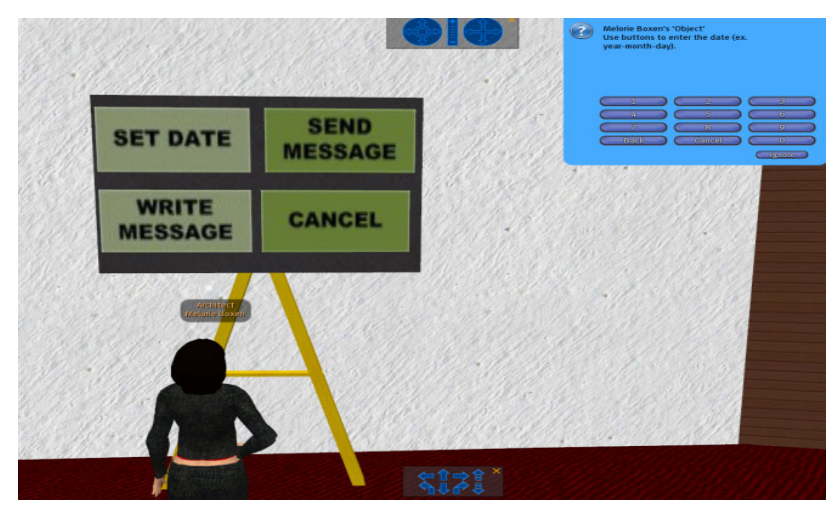

Figure 2. Appointment Setter

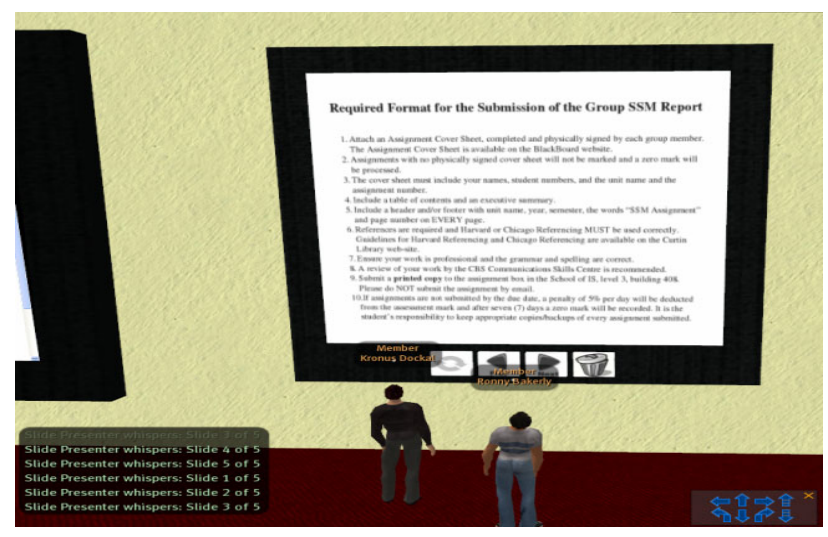

Figure 3. Slide Presenter Board

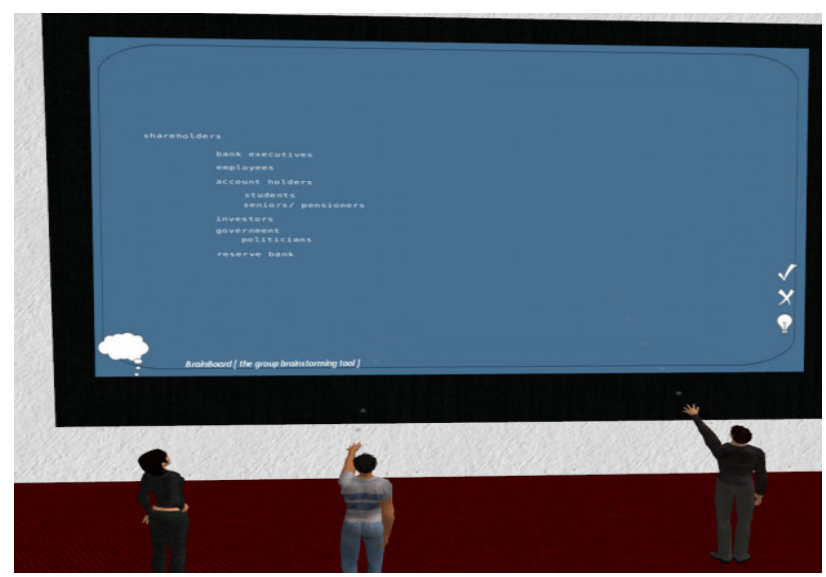

Figure 4. Brainstorming Board

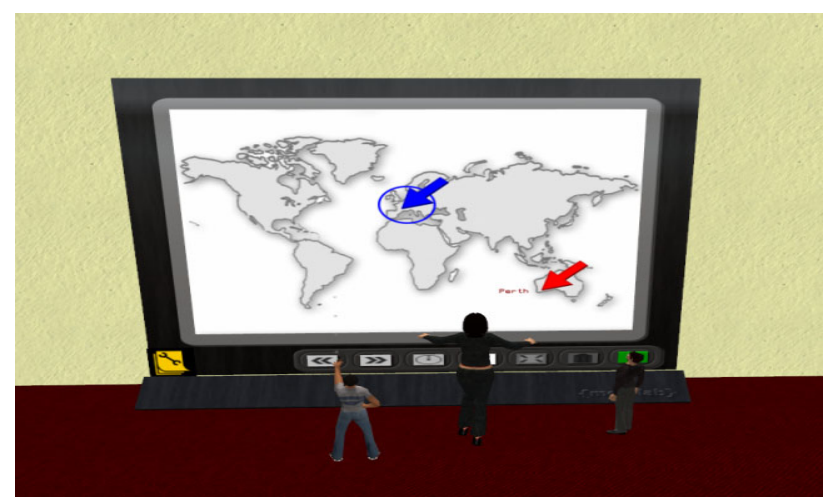

Figure 5. Whiteboard

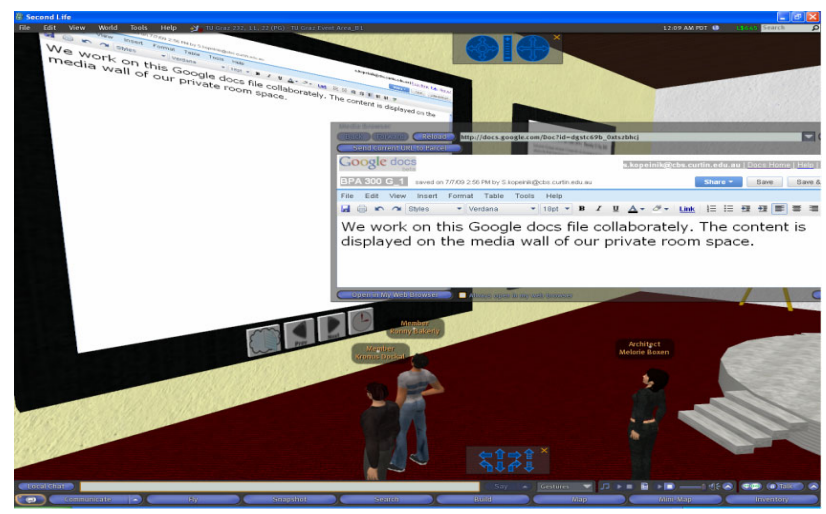

Figure 6. Media Board 


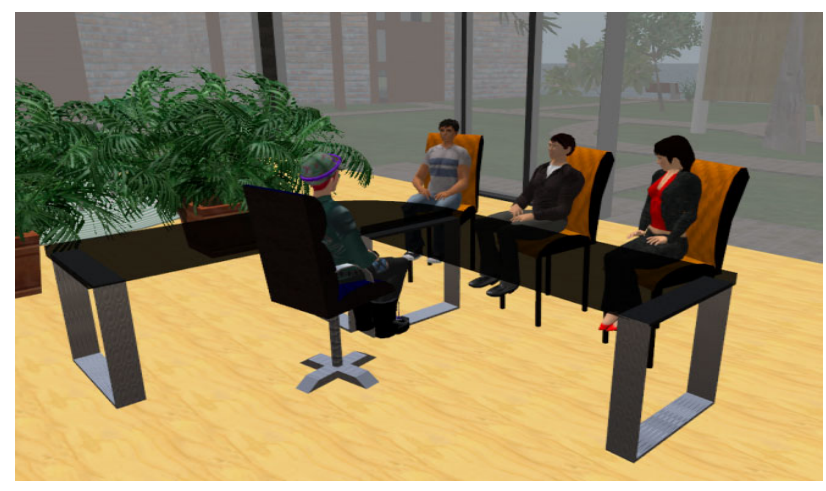

Figure 7. The Lecturer's Office

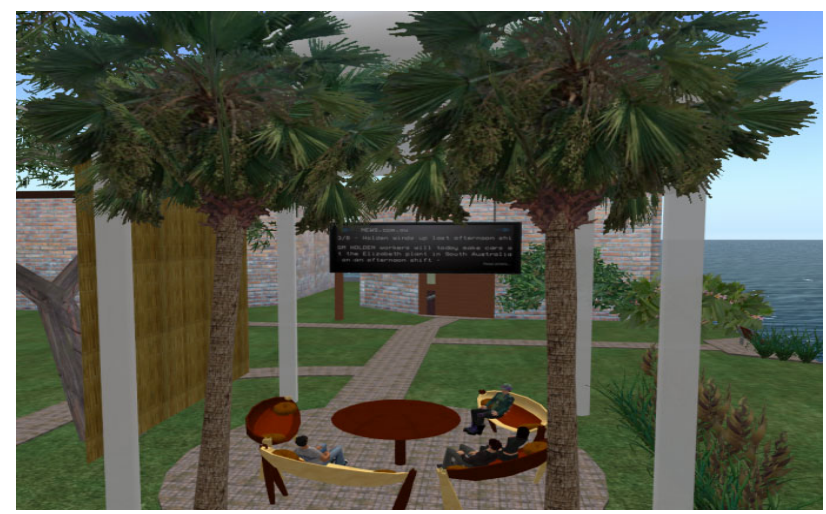

Figure 8. Recreation Area

\section{Students' SuRVEy OF THE SECOND LifE VIRTUAL WORLD LEARNING ENVIRONMENT}

In order to assess and evaluate the use of Second Life as a learning environment, a pre- and a post-survey were developed for students to determine the effectiveness and satisfaction of learning in this environment. The pre- and post surveys are found in Table 1 and 2 respectively. The intent of the pre-survey is to assess the student's prior computer experience and general learning styles. The presurvey contains questions on (i) demographic, (ii) general information and e- learning, and (iii) computer games and Second Life. Specifically, information such as the students' background using computers, the availability of Internet access, interests in playing on-line computer games, the students' learning preference and their attitude towards SL and $3 \mathrm{D}$ virtual worlds as a learning environment were captured. This initial survey is also used to gauge student's willingness to participant in the experiment. The students who accepted to participate in the experiment are required to complete a group assignment in Second Life.

Following the experiment, a post survey asked the students to report on their attitude towards SL and 3D virtual worlds and their perceptions of the design, use, benefits, and limitations of $3 \mathrm{D}$ virtual worlds and the collaborative learning environment implemented in SL. Paper-based surveys were used for both the pre and post survey. To undertake the experiment, ethics clearance was obtained from Curtin University.

\section{EVALUATION RESUlTS FROM USAGE VIEWPOINT}

\section{A. Experiment setup}

The subjects of the experiment are students enrolled in a final year undergraduate degree in a unit (or course) called Business Problem Analysis offered at the School of Information Systems, Curtin University, Perth, Australia. To assess student's performance in the unit, there are 3 assessment items. The students were given the option of completing one of the three assessment items using the SL learning environment. Normal traditional lectures in a face-to-face mode continue to take place. At the beginning of the semester, the SL tutor (also the SL developer) and the lecturer gave an information session about the proposed experiment using SL learning environment and explained that the students had the option of completing one assessment in SL. No penalty was applied to those who chose not to participate in the SL experiment. The students were encouraged to complete a pre-survey questionnaire regardless of their participation in the Second Life research project.

Students who participated in the experiment also completed a post survey (see Table 2). Twenty students enrolled in the unit. As shown in Table 3, of the 20 enrolled students, 16 students completed a pre-survey, and of the 16 students, 6 students volunteered to take part in the SL project.

The unit assessment chosen to be completed in the SL learning environment is an essay that the students had to write about an analysis of a problem and the proposed solution. The essay includes the use of soft system methodology techniques of rich pictures and charts [2].

The students had 4 weeks to complete the essay and the interaction between the students must take place within the SL learning environment. The 6 students who volunteered to participate in this experiment were divided into 2 groups of 3 students. For these two groups, the members worked together on the assignment in a synchronous online mode in SL. In a real setting, the students were located separately and discussed the assignment only using the chat facility and VOIP in SL. Online consultation hours were also provided by the lecturer to the 2 groups of students. This consultation took place with the avatars of the students and the lecturer in either the lecturer's office in SL or the student's group space in SL. Prior to the writing of the essay in the SL learning environment, the SL developer provided assistance for installation and familiarization of SL.

\section{B. Students' Perception of SL Learning Environment}

As indicated earlier, demographic data, level of computer or IT literacy and experience, and awareness and interest of 3D virtual worlds or SL as a learning environment, were collected. As shown in Table 3, the students who enrolled in the unit were predominantly full time students of Generation Y cluster. Of the 16 students, eight were female and eight were male students. There were 3 Australian students and 13 International students. Thirteen students described themselves as experienced computer or IT users, mainly working with MS-Office products. A few had additional knowledge in C\# and HTML. 
TABLE I.

PRE-SURVEY QUESTIONNAIRE

Part A: Demographic data

1. Age: $\square<18 \quad \square 18-24 \quad \square 25-30 \quad \square>30$

2. Home country:

3. Gender: $\square$ male $\square$ female

4. How many days per week are you normally on campus

5. Distance between place of living and university (one way):
$\square$ living on campus
$\square 3-5 \mathrm{~km}$
$\square 6-10 \mathrm{~km}$
$\square 11-20 \mathrm{~km}$
$\square 21-30 \mathrm{~km}$
$\square>30 \mathrm{~km}$

6. I have an Internet connection at home. $\square$ Yes $\square$ No

7. My download is restricted to _ MB per month.

8. Do you work? $\square$ No $\square$ Part time $\square$ Full time If you work part time, please specify the number of hours you work per week.

\section{Part B: General Iinformation and E- learning}

9. How many units are you enrolled in this semester?

10. I usually attend lectures:
$\square$ frequently $(>10)$
$\square$ mostly (6- 9)
$\square$ seldom (2- 5)
$\square$ hardly ever (1)
$\square$ never

11. I attend BPA 300 lectures
$\square$ frequently $(>10)$
$\square$ mostly (6- 9)
$\square$ seldom (2- 5)
$\square$ hardly ever (1)
$\square$ never

12. How do you describe your level of IT experience?

$\square$ Very experienced $\square$ Experienced $\square$ Less experienced

13. Describe your experience of using the computer (programming, using MS-Office, etc).

14. How many hours per week do you use the computer?

15. At what age did you start using computers?

16. When completing work assignments (eg tasks assigned by your employer) I prefer to work:

$\square$ at home $\square$ at work $\square$ other

17. When completing university assignments (eg learning tasks assigned in a unit) I prefer to study:
$\square$ at home
$\square$ at work
$\square$ other

18. My computer meets the minimum requirement for Second Life (attached is a list outlining the minimum requirement).

$\square$ Yes $\square$ No If you answered 'No', list the problems you encountered:

19. Have you used e-learning frameworks (Learning Management Systems such as Blackboard, WebCT, etc)?
$\square$ Yes (go to 19a)
$\square$ No (go to $19 \mathrm{~b}$ )

a. List the frameworks that you are have used:

b. Evaluate the following e-learning framework tools using a scale from 1 (very useful) to 4 (not useful).

unit outline

discussion board

collaboration with peers

learning centered lecture material

other

other

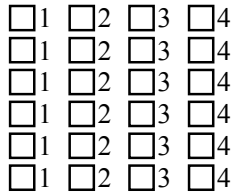

20. Whenever a new technology is released I ......

$$
\begin{aligned}
& \square \text { cannot wait to try it out. } \\
& \square \text { use it as soon as I have the time. } \\
& \square \text { use it when I see a main benefit in it. } \\
& \square \text { just use it if I really have to. }
\end{aligned}
$$

a. What new technologies have you recently used?

b. As an employee, I am willing to apply new technologies in my work task.

$\square$ strongly agree
$\square$ agree
$\square$ strongly disagree

$\square$ strongly

c. As a student, I am willing to apply new technologies in my learning task.

$\square$ strongly agree
$\square$ agree
$\square$ strongly disagree
$\square$ disagree

Part C: Computer Games and Second Life

21. I play computer based games (incl. Playstation, Wii, etc) regularly. $\square$ Yes (go to 21a) $\square$ No (go to 22)

a. How many hours a week do you play?

b. List 3 of your favorite games.

22. I am familiar with Online (Role Playing) Games.
$\square$ Yes (go to 22a)
$\square$ No (go to 23)
a. How many hours a week do you play?
b. List 3 of your favorite games.

23 Playing Online Role Playing Games is entertaining.

$\square$ strongly agree $\square$ agree $\square$ disagree $\square$ strongly disagree

24 Have you used 3D virtual worlds / 3D environments?

$\square$ Yes (go to 24a) $\square$ No (go to 25)

a. Which ones?

b. For what purpose?

25 Are you currently using Second Life?

$\square$ Yes (go to 25a) $\square$ No (go to 26)

a. I have enough time to get familiar with Second Life.

$\square$ strongly agree $\square$ agree $\square$ disagree $\square$ strongly disagree

26 Are you interested in Second Life?
$\square$ Yes
$\square$ No

27 I am participating in the Second Life experiment in BPA 300.

$\square$ Yes (if 'yes', go to 27a) $\square$ No (if 'No', go to 27a)

a. Explain your decision.

28. Virtual 3D worlds (eg Second Life, Java Wonderland, etc) are useful for collaboration.

$\square$ strongly agree

$\square$ agree

$\square$ strongly disagree

$\square$ disagree

$\square$ don't know

Give reasons for your answer. 
TABLE II.

POST-SURVEY QUESTIONNAIRE

Part A: Second Life

(Note:

SA - Strongly Agree, A - Agree, D - Disagree, SD - Strongly Disagree)

1. I had difficulties setting up Second Life. $\square \mathrm{SA} \quad \square \mathrm{A} \quad \square \mathrm{D}$
Explain the main problems.

a. Explain the main problems.

2. Have you used Second Life before working on this project? $\square$ Yes (go to 3) $\square$ No (go to 2a)

a. I had enough time to get familiar with Second Life. $\square \mathrm{SA} \quad \square \mathrm{A} \quad \square \mathrm{D} \quad \square \mathrm{SD}$

b. How many hours did you spend on setup and familiarization with Second Life before you were able to work on your assignment in Second Life?

3. I describe my experiences with Second Life as positive.

$$
\square \mathrm{SA} \quad \square \mathrm{A} \quad \square \mathrm{D} \quad \square \mathrm{SD}
$$

4. Based on your experiences in this experiment, Second Life can improve business collaboration over distance.

$$
\square \mathrm{SA} \quad \square \mathrm{A} \quad \square \mathrm{D} \quad \square \mathrm{SD}
$$

5. I prefer to use Second Life over other technologies / tools to perform collaboration over distance.

$$
\square \mathrm{SA} \quad \square \mathrm{A} \quad \square \mathrm{D} \quad \square \mathrm{SD}
$$

If you disagree or strongly disagree, name at least one technology / tool that you would use.

6. As a result of this experiment, I am going to use Second Life for

(Note: SA - Strongly Agree, A - Agree, D - Disagree, SD Strongly Disagree)

a. learning.

$\square \mathrm{SA} \quad \square \mathrm{A} \quad \square \mathrm{D} \quad \square \mathrm{SD}$

b. communicating with people from other countries.

$\square \mathrm{SA} \quad \square \mathrm{A} \quad \square \mathrm{D} \quad \square \mathrm{SD}$

c. playing games, sports, etc.

$\square \mathrm{sA} \quad \square \mathrm{A} \quad \square \mathrm{D} \quad \square \mathrm{SD}$

d. getting together with friends $\square \mathrm{SA} \quad \square \mathrm{A} \quad \square \mathrm{D}$

e. completing collaborative tasks.

$\square \mathrm{SA} \quad \square \mathrm{A} \quad \square \mathrm{D} \quad \square \mathrm{SD}$

f. other

Part B: Using a 3D Virtual Environment

7. I like to use a similar tool for further projects.

Why?

8. It is easier to meet in virtual than in physical environments.
9. Using $3 \mathrm{D}$ virtual worlds ........

a. is easier to collaborate.

$\square \mathrm{SA} \quad \square \mathrm{A} \quad \square \mathrm{D} \quad \square \mathrm{SD}$

b. raises my motivation to learn.

$\square \mathrm{SA} \quad \square \mathrm{A} \quad \square \mathrm{D} \quad \square \mathrm{SD}$

c. saves travelling time.

$\square \mathrm{SA} \quad \square \mathrm{A} \quad \square \mathrm{D} \quad \square \mathrm{SD}$

d. offers flexibility in respect to time.

$$
\square \mathrm{SA} \quad \square \mathrm{A} \quad \square \mathrm{D} \quad \square \mathrm{SD}
$$

e. other

10. I am distracted by the high amount of information in $3 \mathrm{D}$ virtual world.

$$
\square \mathrm{SA} \quad \square \mathrm{A} \quad \square \mathrm{D} \quad \square \mathrm{SD}
$$

11. List the main advantages you have experienced with using virtual worlds as a collaborative environment.

12. List the main disadvantages you have experienced with using virtual worlds as a collaborative environment.

13. I appreciate using __ in virtual worlds.
a. white board
$\square \mathrm{SA} \quad \square \mathrm{A} \quad \square \mathrm{D} \quad \square \mathrm{SD}$
b. message board
$\square \mathrm{SA} \quad \square \mathrm{A} \quad \square \mathrm{D} \quad \square \mathrm{SD}$
c. Google docs to write an essay
$\square \mathrm{SA} \quad \square \mathrm{A} \quad \square \mathrm{D} \quad \square \mathrm{SD}$
d. google docs to prepare a presentation
$\square \mathrm{SA} \quad \square \mathrm{A} \quad \square \mathrm{D} \quad \square \mathrm{SD}$
e. text chat
$\square \mathrm{SA} \quad \square \mathrm{A} \quad \square \mathrm{D} \quad \square \mathrm{SD}$
f. voice over IP
$\square \mathrm{SA} \quad \square \mathrm{A} \quad \square \mathrm{D} \quad \square \mathrm{SD}$

g. other

14. The virtual learning environment enhanced the outcome of our project.

$\square$ SA $\quad \square$ A
Give reasons for your answer.

15. I describe my experience with this particular learning environment as positive.

$$
\square \mathrm{SA} \quad \square \mathrm{A} \quad \square \mathrm{D} \quad \square \mathrm{sD}
$$

If you disagree or strongly disagree, what would you change in the learning environment to improve it to a satisfactory level?

15. To complete the assignment task I used the learning environment for ..... (multiple options possible)
$\square$ the first
$\square$ the last
$\square$ all group meetings. number group meetings. number group meetings.

16. To complete the assignment task I used the learning environment $\square$ at home $\square$ at university $\square$ other 
TABLE III.

SUMMARY OF PRE-SURVEY - DEMOGRAPHIC AND LEVEL OF IT EXPERIENCE

\begin{tabular}{|l|c||c|c|}
\hline \multicolumn{2}{|l||}{ Demographic Data } & Computer / IT Experience & \\
\hline Age Group & & Level of IT Experience & 13 \\
\hline $18-24$ & 14 & Highly Experienced & 3 \\
\hline $25-30$ & 2 & Little Experienced & \\
\hline \hline \multirow{2}{*}{ Gender } & & $\begin{array}{l}\text { Level of e-learning (LMS) ex- } \\
\text { perience }\end{array}$ & 16 \\
\hline Male & 8 & Experienced & 0 \\
\hline Female & 8 & No Experienced & 14 \\
\hline \hline Student Type & & Computer meet SL requirement & 2 \\
\hline Australian & 3 & Yes & 6 \\
\hline Non-Australian & 13 & No & 10 \\
\hline \hline Student Type & & Participating in this experiment & \\
\hline \hline Part-Time & 1 & Yes & No \\
\hline \hline Full-Time & 15 & Nex & 14 \\
\hline \hline
\end{tabular}

In order to use the SL learning environment without technical difficulties, we asked the students if they had trouble meeting the system requirements. Interestingly, as shown in Table 3, only 2 students had problems meeting the system requirements. Table 4 shows that students are willing to adopt new technology when it comes to completing learning activities (94\%) and work tasks (100\%). Despite the good attitude and interest in new technologies, only 6 students have decided to participate in the experiment.

TABLE IV

SUMMARY OF PRE-SURVEY - STUDENTS' TECHOLOGY ADOPTION AND COMPUTER/ONLINE GAMES

\begin{tabular}{|c|c|}
\hline \multicolumn{2}{|c|}{ STUDENTS' TECHNOLOGY ADOPTION AND LIFE STYLES } \\
\hline Usage of computer per week & \\
\hline Less than 30 hours per week & 7 \\
\hline 30 hours or more per week & 9 \\
\hline \multicolumn{2}{|c|}{ Willing to use new technology in my learning tasks } \\
\hline Yes & 15 \\
\hline No & 1 \\
\hline \multicolumn{2}{|c|}{ Willing to use new technology in my work tasks } \\
\hline Yes & 16 \\
\hline No & 0 \\
\hline \multicolumn{2}{|l|}{ Familiar with online role playing games } \\
\hline Yes & 9 \\
\hline No & 7 \\
\hline \multicolumn{2}{|c|}{ Online role playing games are entertaining } \\
\hline Yes & 11 \\
\hline No & 5 \\
\hline \multicolumn{2}{|l|}{ Playing computer games regularly } \\
\hline Yes & 11 \\
\hline No & 5 \\
\hline
\end{tabular}

We asked the students who preferred to complete the assignment in a normal mode (i.e. not using SL learning environment) to give some reasons why they had chosen not to participant in the experiment. The students perceived that there was an increased workload through having to learn how to use the SL learning environment, the pressure of time, and the concerns with instability (e.g. downtime, access and maneuvering concerns in SL) of the learning environment. Another important aspect was that students are familiar with face-to-face collaboration and how to negotiate and collaborate but they fear that they are not experienced enough in the virtual environments. One of the respondents stated that "It takes a lot of time to get familiar with the game and it seems face to face is more direct and easy to understand."

Nine students spent 30 hours or more per week on their computers, either completing learning tasks or playing computer games. A student noted that, "I would like to try out anything new ...I know I will learn a lot from using it." Nine students are familiar with online role playing games. Eleven students thought that online role playing games are entertaining and the same numbers of students play computer games regularly.

TABLE V.

SUMMARY OF PRE-SURVEY - FAMILIARITY OF 3D VIRTUAL WORLDS

\begin{tabular}{|c|c|}
\hline \multicolumn{2}{|c|}{ Familiarity with 3D Virtual Worlds Learning Environment } \\
\hline Currently using 3D/VW environment & 7 \\
\hline Yes & 9 \\
\hline No & \\
\hline \hline Currently using Second Life & 1 \\
\hline Yes & 15 \\
\hline No & \\
\hline Yes & 9 \\
\hline No & 7 \\
\hline Perception of VW/SL as a collaborative learning envi- \\
ronment & 10 \\
\hline Useful & 3 \\
\hline Not Useful & 3 \\
\hline Don't Know & \\
\hline
\end{tabular}

As shown in Table 5, although 9 students indicated an interest in using SL, with only 1 is currently using SL, and 10 perceived $3 \mathrm{D}$ virtual worlds or SL as a useful collaborative tool. A volunteered student participating in the experiment indicated that he/she enjoys playing games and see a connection and integration between entertainment and education, a trait of a Generation Y. To this, the following comment was provided, "... because it is something new for me and basically I love playing games, so why not do assignment like I am playing the games."

According to Griffith and Hunt [10], males are more likely to occupy themselves with computer games but are also easier to motivate to play online games than females. In this regard, we expected more male students to participant in this experiment, however, 5 out of 6 volunteers turned out to be female. One surprising result of the survey was that the 6 students who volunteered to participate in this experiment spend less time on computer games than the students who did not volunteer.

The 6 students were asked to complete a post-survey following the submission of the assignment. One of the limitations of this study was the small sample size, although it was a decision that was made deliberately to allow the students to volunteer rather than be instructed to use the new SL learning environment. Nevertheless, the results of the findings reveal the perceptions of this group of students. 
In general, the students had no difficulties in setting up SL and they spent an average of 2.25 hours to get themselves familiar with this environment. In terms of the students' perception of using SL as a learning environment, the following gives a snapshot of this:

- 5 out of 6 planned to work on collaborative tasks using SL

- 5 out of 6 perceived using 3D virtual worlds offers flexibility in respect to time

- 5 out of 6 perceived using 3D virtual worlds saves travelling time

- 5 out of 6 were going to get together with friends in SL

On the negative front, the students were distracted by the poor interface usability of SL. The students found that $\mathrm{SL}$ is not intuitive and it was difficult to operate the user interface of the collaboration tools. The missing document sharing feature was one of the major limitations. To overcome this, the students were given the option to use Googledocs and this was a well appreciated outcome. In terms of the interaction tool, the students rated the text chat as more convenient than the use of VOIP. One group also indicated the use of Skype in their communication.

The students felt that they were under a lot of pressure trying to complete the assignment in an environment that they were not $100 \%$ familiar with. Some communication among group members had broken down due to some members' familiarization problems. Several students found using SL was time consuming. They did not like the online consultation hours. A part of the frustration they encountered was the inability to express emotions with the avatars, although they communicated using VOIP or Skype. They also found limitations of the available tools where the students were unable to explain their thoughts or use drawing tools to sketch their ideas.

Regardless of the previous remarks, on the positive sides, the students acknowledged that it was more convenient to meet in SL. Some comments supporting this were:

- 'Even though with our different schedules I believe Second Life made it easier for our group to meet'

- 'Easier to work around group members other commitments'

- 'Time saving in regard to travelling time; working at home'

- 'Flexible-(able to) meet group members even during night time'

- Solves the problem of transportation issues

Using SL also helped the students to plan and organize their work and the students found a single environment helped them to work together effectively. The comments below showed students found SL helpful.

- 'Helped organise(d) the group'

- 'Easier to put documents together because they are online and we can each add to the document'

- '(The) environment provides media to leave messages or ideas for other group members'

- 'Whatever work done by a group member can be continued by another group member later on'

- 'Meetings (can be) minuted through chat'
Some students found the SL learning environment encouraging and conducive to learning. A comment from a student was that he/she 'appreciate(s) the furniture created in the virtual world as it makes the environment looks more realistic and exciting'. This student also appreciated the privacy of each room where they discussed the assignments. Almost all of the students indicated that improvements are required for the interface and usability features of the Whiteboard, Media Board, and Brainstorming Board. Ease of navigation and a user-friendly interface are two main features that are required for efficient and effective learning to take place in SL.

In general, the overall students' attitude toward SL and $3 \mathrm{D}$ virtual worlds was one which was positive and the survey responses indicated that the students supported the use of SL provided that the design, navigation and features of the collaboration tools enhance the students' learning experience. Without this, the students will be reluctant to adopt a learning environment which was tedious and challenging to use.

\section{EVAlUATION RESUlTS FROM DEVELOPMENT VIEWPOINT}

The dedicated programming language in SL, the Linden Script Language (LSL), is simple to use, in particular for developers who already have background in programming [27]. A variety of online tutorials, wikis and forums on LSL are readily available. The LSL user community provided valuable support during the implementation of the SL learning environment. Developing more complex functionalities, however, can cause difficulties since debugging tools are not supplied.

We did not encounter any difficulties when creating the $3 \mathrm{D}$ content using the provided standard objects. Depending on the outcomes required for the learning environment, the Second Life's in-world building tools can provide an alternative to the regular 3D modeling tools (e.g. Blender). Furthermore it is time consuming to integrate objects when the object are created outside the platform; e.g. size of objects and textures need to be adapted. Linden Labs also charges for the uploading of images, sounds and animations. These images, sounds or animations may be necessary to achieve the learning outcomes.

One of the biggest issues influencing our design was the restrictions imposed on some of the SL functionalities. Some of these issues are listed below:

- Avatars can look into closed buildings or rooms

To protect users' intellectual property and to control plagiarism it is necessary to screen certain objects from unauthorized access. The creations of walls or scripting doors do not keep unauthorized avatars from every building or rooms as they can look into the rooms with skilled operation of their camera views.

\section{- Allocation of rights}

Assigning rights to users are problematic. To do this, one is required to restrict objects accessibility to specific groups or users via scripts. Given that group areas are equipped with five different collaboration tools and an entrance door, each time a change occurs, the rights must be re-configured. This means that the administration costs will increase in proportion to the sequence of alternation of user groups. 
- $\quad$ Text requires textures to visualize letters

Assigning rights to users are problematic. To do this, one is required to restrict objects is currently also not possible. Since our aim is to build an environment for collaborative learning activities, this has become one of the most fundamental shortcomings.

- It is only possible to play one media per parcel As explained in the previous section on Media Board, a workaround using Google docs was implemented to substitute in-world document sharing. Therefore one media was streamed in each collaboration room. This limitation combined with the visibility restrictions of the media influenced our design significantly.

- No possibility to scroll media

Even though web pages can be displayed at Second Life walls, no scrolling option is available. Workarounds might be necessary to offer this feature within the learning environment.

- The amount of allowed prims per parcel is limited It is easy to exceed the number of prims; and this issue needs to be kept in mind throughout the construction and design phase.

- Difficulty to develop user-friendly collaboration tools User dialogs are not easy to work with. Even though there is a built-in function called llDialog that generates dialog boxes with a text and buttons, it takes too much time between the event of pushing a button till the implemented reaction is performed.

- Usability of text chat

Using text chat is an interaction option, however, this is often perceived as inconvenient.

- Usage of learning environment by multiple groups Another challenge is to provide rooms and tools to multiple working groups that interact sequentially within a certain period of time. Content on Slide Presenter Boards, Brainstorming Boards and Whiteboards, remains static on the equipment. In order to provide this functionality, future research will continue with a work on dynamic changeable learning rooms.

- High administration cost of access right

In LSL implemented http responses and requests allow us to address the administration costs caused by the allocation of rights. Therefore our next implementation will include the realization of a web interface, used to meet incoming configuration needs.

\section{A. Lecturer's and Tutor's Perception of SL Learning Environment}

Over the last five years, educators have been increasingly challenged to prepare themselves to become $21 \mathrm{st}$ century educators who are capable of meeting the learning needs of their future students, especially given the dynamic nature of educational technology [32]. The lecturer, who was not familiar with SL before the experiment, was asked to comment on the design and usability features of SL and the benefits of incorporating a SL learning environment in the unit. Navigating through the SL learning environment require some familiarization and one has to spend some time to be familiar with navigating the avatar around the island.

Setting up a learning environment in SL requires a lot of planning, effort and time. It is recommended that the SL learning environment be used for more productive activities. The lecturer indicated that SL would allow students to work remotely. One of the disadvantages of interacting in SL was the difficulty in knowing who you interacting with because of the use of avatar names. It was suggested that names be given to the buildings in the SL learning environment. It may also be helpful to provide a map on the island.

From the lecturer's point of view, using the SL learning platform was time consuming compared to teaching in traditional classrooms. Another observation was that the lecturer noted that the students were not very familiar with the SL application and this has hampered their learning experience. Although installation assistance of SL, an introduction of SL and the particular environment were presented to the students, an extensive and thorough training to staff and students should be provided for all future learning delivered in the SL environment. Another recommendation was to provide ongoing technical support (such as help desk) to the participants, especially at the onset of using the environment. The technical assistant's perception was that additional tutoring lessons in the labs could improve the students' working abilities in the virtual learning environment.

From the tutors' viewpoint it is worth mentioning that although individual support for installation, getting familiar with the environment and problem solving during the operational phase were offered, only one student took up the offer. Although the students had some problems operating SL and using the learning environment, it turned out that one of the main reasons for not taking the offer of support was the feeling that they were too exposed. To overcome this, it is recommended not only to give a short introduction at the beginning of the unit, but also to give a SL training session before the students start to collaborate in the environment.

\section{CONCLUSIONS AND FUTURE WORK}

As the learning and teaching delivery continue to evolve over time and given the superior technological advancement, our society has begun to assess new approaches to explore educational, vocational and life-long learning. As ICT continues to evolve, educators must shift from passive lectures to incorporate effective teaching strategies, personalization and flexibility in course delivery. Governments are working closely with institutions' academics and administrators to find a better way to reach the new generations of learners, the work force population and those living in the remote and regional areas. Opportunities to increase access and participation rates to higher education or vocational training exist with the availability of modern learning environments that encompass the use of 3D virtual worlds. 3D virtual worlds learning environment including Second Life is still at its infancy and the technology and application surrounding these will continue to develop and mature.

From this study, the perspective of the users (both students and teachers) affirmed that it is important that all users, regardless of their generations, are familiar with the environment. As indicated in the findings, the students and 
staff found the learning environment tedious. It is, therefore, important that the students are given ample training to ensure that the tools in the 3D learning environment are not a hindrance but the availability of the tools would enable them to work with other members collaboratively. Although the responses from the students are generally positive and the responses from the staff are encouraging, the limitation of this experiment lies in the small sample size. It is hoped that the setup of this learning environment along with the pre and post surveys will be administered for another course in the near future.

Another perceived challenge for the students who are mostly Generation Y may find that the separation between virtual reality and reality is not as well-defined [22, 25, 26]. Often, when faced with difficulties and challenges, the students seem to fall back to the traditional mode of learning. Challenges and lessons that we have learned from this exploratory experiment include the need to provide rooms and tools for multiple working groups to use and interact. The tools provided, such as the content on Slide Presenter Boards, Brainstorming Boards and Whiteboards are static tools. For effective collaboration to take place and to offer more functionalities, future research must continue to find a way to offer these tools dynamically which are more flexible and easier to use. It is also a time consuming task to organize access rights on user and group level in world, especially when several tools and areas in the learning environment needs to set specific access rights. Thus in future, we plan to design a web application to handle those rights in a more convenient and efficient way.

\section{REFERENCES}

[1] AngryBeth Shortbread (n.d.). Second Life, MetaLabs Communa Whiteboard, from http://slurl.com/secondlife/Gourdneck/194/236/ 67 and http://metalab.blogspot.com/2006/06/communal-whiteboa rd.html

[2] BPA Unit Outline (2009). Business Problem Analysis 300, School of Information Systems, Curtin University, Australia, Retrieved on 5 Mar 09 from http://www.business.curtin.edu.au/busi ness/current-students/unit-and-course-information/undergraduateunit-information

[3] Bradley, D., Noonan, P., Nugent, H, and Scales, B. 2008. Review of Australian Higher Education Final Report, Department of Education, Employment and Workplace Relations, Australia, Retrieved on 5 July 09 from www.deewr.gov.au/he review finalreport

[4] Bransford J.D., Brown A.L., Cocking R.R. (Eds.) (2000). How People Learn: Brain, Mind, Experience, and School. Expanded Edition. Washington DC: National Academies Press.

[5] Brown, J.S. (1999). Learning, Working \& Playing in the Digital Age. Transcript of the talk at 1999 Conference on Higher Education of the American Association for Higher Education, last retrieved 1 Feb 2008, from http://serendip.brynmawr.edu/sci_edu/ seelybrown/

[6] Brodo, J. A. (2006). Today's Ecosystem of e-learning. Trainer Talk, Professional Society for Sales \& Marketing Training, Vol. 3 , No 4, 2006, last retrieved Jan 26th, 2008 from http://www.enewsbuilder.net/salesmarketing/e article000615779. cfm.

[7] Burra, K (2002). Beyond the Frontiers of Traditional eLearning Whitepaper, NIIT Ltd, last edited, Feb. 9th, 2002, last retrieved Feb 6th, 2008, from http://niit.com/Corp/India/ASP/downloads/ pdf/Beyond $\% 20$ the $\% 20$ frontiers.pdf.

[8] Department of Education, Employment and Workplace Relations (DEEWR), Higher Education Statistics Collections, last retrieved Aug 26th, 2008 from http://www.deewr.gov.au/highered/statpu bs.htm

[9] Dudeney Ge (n.d.). Second Life, EduNation, BrainBoard V4.0 International Character Set [boxed], from http://slurl.com/
secondlife/EduNation\%20II/132/215/22/ and https://www.xstr eetsl.com/modules. php? name $=$ Marketplace $\&$ file $=i$ item $\&$ ItemID $=8$ 76838

[10] Griffiths, M.D., Hunt, N. J. A. (1995). Computer Game Playing in Adolescence: Prevalence and Demographic Indicators. Journal of Community \& Applied Social Psychology, 5(3), pp. 189-193 (doi:10.1002/casp.2450050307)

[11] Gütl, C. (2008). Enhancements of Meeting Information Management and Application for Knowledge Access and Learning Activities. Journal of Universal Computer Science (J.UCS), 14, 10, $1625--1653$.

[12] Gütl, C., \& Chang, V. (2008). Ecosystem-based Theoretical Models for Learning in Environments of the 21st Century. International. Journal of Emerging Technologies in Learning (iJET), Vol 3 (2008), 50-60.

[13] Kappe, F., \& Gütl, C. (2009). Enhancements of the realXtend framework to build a Virtual Conference Room for Knowledge Transfer and Learning Purposes. EDMEDIA 2009 (accepted for publication).

[14] Linden Labs (2009). Second Life - What is Second Life? Linden Lab, San Francisco, USA, last retrieved 22 August, 2009 from http://secondlife.com/whatis/

[15] Pirie, C. (2004). E-Learning Ecosystems: The Future of Learning Technology. Chief Learning Officer Magazine, September 200, last retrieved 29 Jan 2008, from http://www.clomedia.com/ content/templates/clo article. asp?articleid $=618$.

[16] Reiser, R. A. (2001). A History of Instructional Design and Technology: Part II: A History of Instructional Design. ETR\&D, Vol. 49, No. 2, 2001, pp. 57-67

[17] Sedita, S.R. (2003) Back to "Tribal Fires"? Explicit and Tacit Knowledge, Formal and Informal Learning, Towards A New Learning Ecosystem. DRUID Summer Conference 2003 on Creating, Sharing and Transferring Knowledge - The Role of Geography, Institutions and Organizations. Copenhagen, June 12-14, 2003.

[18] Thompson, J. (2007). Is Education 1.0 Ready for Web 2.0 Students? Innovate Journal of Online Education, 2007, Vol. 3, No. 4.

[19] Wilkinson, D. (2002). The Intersection of Learning Architecture and Instructional Design in e-Learning. 2002 ECI Conference on e-Technologies in Engineering Education: Learning Outcomes Providing Future Possibilities, pp. 213-221.

[20] Witherspoon, J. (2006). Building the Academic EcoSystem: Implications of E-Learning. Vol. 3. No. 3., March 2006, last retrieved Jan. 2nd, 2008, from http://www.itdl.org/Journal/ Mar 06/article01.htm

[21] Monaco, M and Martin, M. (2007) The Millennial Student: A New Generation of Learners, Athletic Training Education Journal; 2 (Apr-Jun):42-46 42

[22] Billings, D. (2004, May/Jun). Teaching learners from varied generations. The Journal of Continuing Education in Nursing, 35(3), 104-105. Retrieved on 1 October, 2009 from ProQuest Education Journals.

[23] Generation Y Perspectives. (2007). Retrieved on 6 October, 2009 from http://www.opennasa.com/files.

[24] Generation Y goes to work. (2008). Retrieved on 6 October, 2009 from http://www.economist.com/businessfinance/displayStory.cf m? story id $=12863573$

[25] McCrindle. M (2002). Understanding Generation Y. Retrieved on 6 October, 2009 from http://www.learningtolearn.sa.edu.au/ Colleagues/files/links/UnderstandingGenY.pdf

[26] Duan, M. (2009). Businesses untangle the Gen Y knot. Business Journal, August. Retrieved on 6 October, 2009 from http://sanjose.bizjournals.com/sanjose/stories/2009/08/03/focus1. html\#

[27] Second Life LindeX ${ }^{\mathrm{TM}}$ Market Data (n.d). Retrieved on 6 October, 2009 from http://secondlife.com/statistics/economymarket.php

[28] Second Life Avatar (n.d). Retrieved on 6 October, 2009 from http://secondlife.com/community/avatar.php

[29] Vygotsky (n.d) Social Development Theory. Retrieved on 6 October, 2009 from http://www.learning-theories.com/vygotskyssocial-learning-theory.html

[30] Oblinger, D.G. and Oblinger, J.L. (2005). Educating the net generation. Retrieved October, 1, 20097 from http://www.educ ause.edu/educatingthenetgen 
[31] Shih, T. K., \& Hung, J.C. (2007). Future directions in distance learning and communication technologies. Hershey: Information Science Publishing.

[32] Williams, M.K., Foulger, T. S. and Wetzel K. (2009). Preparing Preservice Teachers for 21 st Century Classrooms: Transforming Attitudes and Behaviors About Innovative Technology, Journal of Technology and Teacher Education, 17 (3) 393-418.

\section{ACKNOWLEDGMENTS}

This paper is part of research resulting of visiting academic activities of Simone Kopeinik and Christian Gütl in the School of Information Systems at Curtin University of Technology. The visits were supported and sponsored by School of Information Systems and Curtin Business School, Curtin University, Perth, Australia and Institute for Information Systems and Computer Media (IICM) at Graz University of Technology, Austria.

\section{AUTHORS}

Vanessa Chang Ph.D. is with the School of Information Systems, Curtin Business School, Curtin University, G P O Box U1987, Perth, Western Australia, Australia. (email: vanessa.chang@curtin.edu.au).
Christian Gütl Dipl.-Ing. Dr. techn. is with Graz University of Technology, Institute for Information Systems and Computer Media, Inffeldgasse 16c, A-8010 Graz. He is also an Adjunct Research Professor with the School of Information Systems, Curtin University, G P O Box U1987, Perth, Western Australia, Australia. (email: cguetl@iicm.edu).

Simone Kopeinik a Master student with Graz University of Technology, Institute for Information Systems and Computer Media, Inffeldgasse 16c, A-8010 Graz and a research associate with the School of Information Systems, Curtin Business School, Curtin University, G P O Box U1987, Perth, Western Australia, Australia. (email: meins@sbox.tugraz.at).

Robert Williams, Senior Lecturer with the School of Information Systems, Curtin University, G P O Box U1987, Perth, Western Australia, Australia. (email: robert.williams@cbs.curtin.edu.au).

This article was modified from a presentation at the International Conference of Interactive Computer Aided Learning ICL2009, September 2009 in Villach, Austria. Submitted 19 October 2009. Published as resubmitted by the authors on 2 November 2009 . 